\title{
MiR-221/222 Promote the Growth of Malignant Glioma Cells by Regulating Its Target Genes
}

\author{
Zhang Chunzhi1,2, Jiang Tao ${ }^{3}$, Wang Jinhuan, ${ }^{4}$, Cheng Jinquan ${ }^{5}$, \\ $\mathrm{Pu}$ Peiyu $^{2}$ and Kang Chunsheng 2 \\ ${ }^{1}$ Department of Radiation Oncology, Tianjin Huanhu hospital, Tianjin, \\ 2Department of Neurosurgery, Laboratory of Neuro-Oncology, Tianjin Medical University \\ General Hospital, Tianjin Key Laboratory of Nerve Injury, \\ Variation and Regeneration, Tianjin, \\ ${ }^{3}$ Department of Neurosurgery, Tiantan Hospital, Capital Medical University, Beijing, \\ ${ }^{4}$ Department of Neurosurgery, Tianjin Huanhu hospital, Tianjin \\ ${ }^{5}$ Department of Molecular Oncology, H.Lee Moffitt Cancer and Research Institute, Tampa, \\ $1,2,3,4$ China \\ ${ }^{5}$ USA
}

\section{Introduction}

MicroRNAs (miRNAs or miRs) are a class of small noncoding RNAs of 19 22 nucleotides, and repress protein expression at the posttranscriptional level through imperfect or perfect base pairing with 3 untranslated region of the target mRNA in mammalian cells, leading to its reduced translation or mRNA degradation. Although miRs are thought to be involved in various biological processes, including development, differentiation, cell proliferation, cell death, and so on, accumulating evidence suggests that alterations of their expression may play a role in the development of human cancers(1-4). Specific miRNAs have been demonstrated to be deregulated in diverse cancer subtypes including lymphoma, colorectal cancer, lung cancer, breast cancer, papillary thyroid carcinoma, hepatocellular carcinoma, and glioblastoma(5-13). Ciafre et al. used microarray method to compare the global expression levels of 245 miRNAs in glioblastoma tissue with normal brain tissue and found that the expression of miR-221 was strongly upregulated in glioblastoma cells. They identified nine overexpression miRNAs including miR-221 and miR-222(miR-221/222) cluster (13). This chapter review how miR-221/222 cluster regulated glioma cell phenotype and it`s mechanism.

\section{2. miR-221 and miR-222 cluster regulated glioma cell phenotype and it's mechanism}

In Ciafre study, they found that miR-221 and miR-222 overexpress in glioma tumor tissue and glioma cell line compare to normal brain tissue, as well as our microarray results. So, we question what biogenesis of miR-221 and miR-222 and this cluster miRs function. 


\subsection{Biogenesis of miR-221 and miR-222 and this tow miRs location}

MiR-221, miR-222 genes are clustered chromosome Xp11.3 in tandem. When zhanglilei research retinitis pigmentosa, they discover miR-221 and miR-222 genes. Two miR genes are located near the telomeric end of deletion $\sim 700 \mathrm{bp}$ apart(mir-221:45,361,839-45,361,948 and mir-222 : 45,362,675-45,362,784) (14). Like some other clustered miRNA genes, two miRNA genes is high similariry in sequence and they might be transcribed as polycistrons (Fig 1).
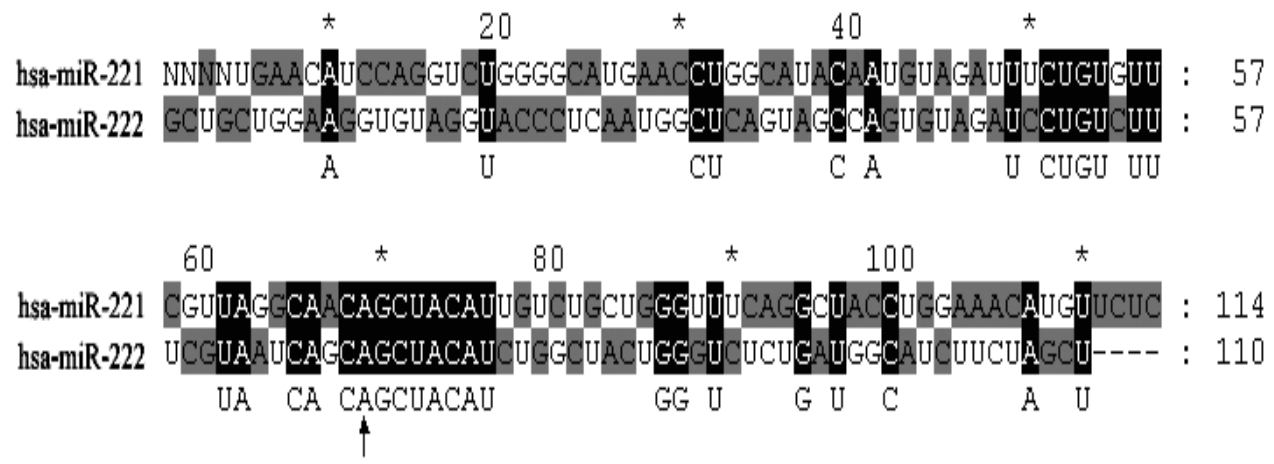

Fig. 1. A schematic representation defines the miR-221 and miR-222 sequences (arrow indicates identical seed sequences AGCUACAU as shown in GeneDoc, www.psc.edu/biomed /genedoc).

As well as the other miRs, biogenesis of miR-221 and miR-222 are a multi-step process beginning with transcription by RNA polymerase $I I$ of a primary transcript, called primiRNA. This precursor is cleaved to form a 70nt long stem-loop precursor RNA(premiRNA) by an RNAse III type endonuclease called Drosha inside the nucleus. RanGTP exportin 5 transports pre- miRNA to the cytoplasm, where another RNAse III, Dicer, cleaves the stem-loop structure to produce 19 23 nucleotide miRNA duplexes. That one of the two RNA strands is then included into the RNA-induced silencing complex(RISC) form asymmetric RISC assembley. Asymmetric RISC assembley is also called miRNP. It inhibit translation or mRNA degradation by miRNA complete pairing or incomplete pairing with mRNA 3'UTRs.(15-17)

\section{2 miR-221 and miR-222 cluster regulated glioma cell phenotype in vitro}

We already proved that miR-221 and miR-222 upregulted in glioma compared to normal brain tissue, and knowed this two miRs biogenesis and location in chromosome. Furthermore, we ready to research how the cluster miRs affect glioma cell phenotype, including proliferation, cell cycle, apoptosis, invasion and radiosensitivity, in vitro.

Our previous work identified that a functional overlap between miR-221/222 in modulating glioma cell phenotype. So, we knocked down or ectopic express miR-221/222 to study their function. Firstly, by northern blot, it is identified that pMSCV-miR-221/222 increased miR-221 and miR-222 level and anti-miR-221/222(AS-miR-221/222 or As-miR-221/222) knocked down miR-221 and miR-222 level (not show).By MTT assay, the glioma U251 cell proliferation rate in different transfected cells was measured. It was shown that the cells transfected with anti-miR221/222 were proliferated at a significantly lower rate than the other three groups (Figure 2). 
Moreover, the cells transfected with pMSCV-miR-221/222 proliferated at a significantly higher rate than the control and the scramble groups (Figure 2). These data demonstrated that the growth rate of glioma cell could be co-modulated by miR-221 and miR-222. The result were also proved in the other tumors. Agami $\mathrm{R}$ et al found that miR-221 and miR-222 promote cancer cell proliferation(18). Frenquelli $\mathrm{M}$ et al also identified that miR-221 and miR-222 promote cancer cell proliferation in chronic lymphocytic leukemia(19). The same result were also proved in human prostate carcinoma cell lines, human thyroid papillary carcinomas, human colorectal carcinoma, and so on(20-22).

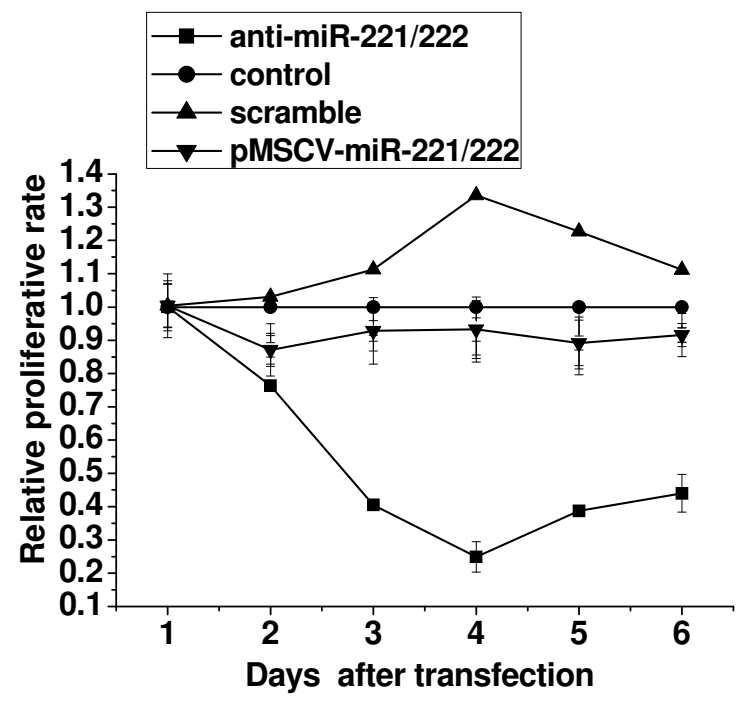

Fig. 2. As-miR-221/222 decrease cell proliferation. MTT assay show that the cells transfected with As-miR-221/222 were proliferated at a significantly lower rate than the other four groups. The latitudinal axis represented days after cell implantation in the 96-well plate. The cell proliferation rate in parental U251 glioma cells was presented as $100 \%$.

The cell cycle distribution and cell apoptosis were analyzed by flow cytometry. The cell cycle distribution showed that the G0/G1 phase percentage of control, scramble treated cells was $28.6 \%, 26.0 \%$, respectively; while the fraction of anti-miR-221/222 treated cells was $46.2 \%$ and the fraction of pMSCV-miR-221/222 treated cells was $22.3 \%$. The S phase fraction in control, scramble treated cells, anti-miR-221/222 treated cells, pMSCV-miR-221/222 treated cells was $56.8 \%, 57.2 \%, 26.8 \%, 60 \%$, respectively. No statistical significance of G2/M phase percentage was detected among the four groups (Fig. 3). Frenquelli $M$ et al also identified that miR-221/222 promote cancer cell into $\mathrm{S}$ phase in chronic lymphocytic leukemia. They synchronized cells in the G1 phase and analyzed by flow cytometry the cellcycle distribution at 4, 6, and 24 hours after cell-cycle block release. The result document that miR-221- and miR-222-transduced cells progressed more quickly through the cell-cycle phases (19). The same result was also proved in human prostate carcinoma cell lines, human thyroid papillary carcinomas, human colorectal carcinoma, and so on (20-22). 

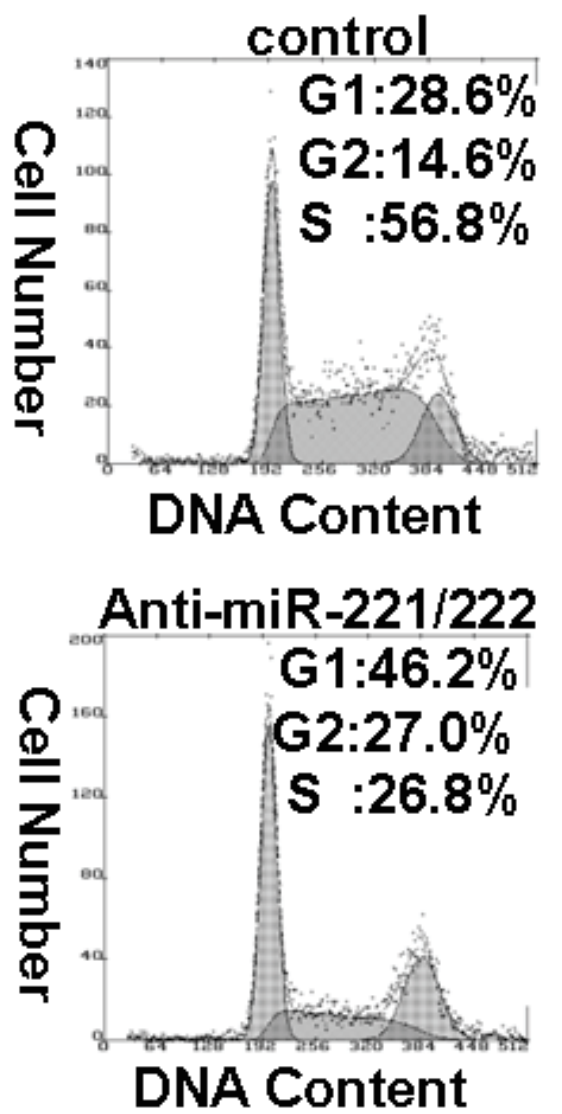

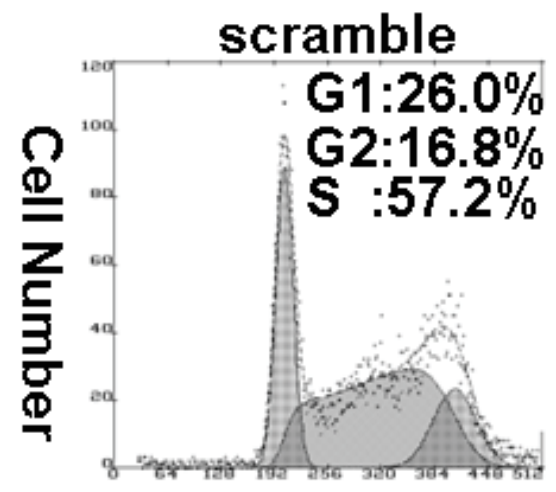

DNA Content

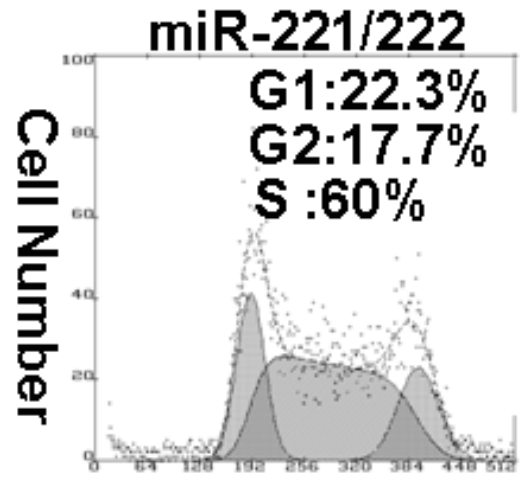

DNA Content

Fig. 3. Co-suppression of miR-221/222 expression by as-miR-221/222 induce G1 arrest in U251 cell. Transfected and control cells were harvested by trypsinization, washed and fixed overnight. Nuclei of cells were stained with propidium iodide, a total of 10,000 nuclei were examined. By flow cytometry analysis, the rate of cell in G1 in anti-miR-221/222 group was higher significantly than the other four groups.

Moreover, miR-221 and miR-222 inhibit glioma cell apoptosis. To examine biological significance of miR-221 and miR-222 in glioma, glioma U251 cells were treated with antimiR-221 /222. Interestingly, annexin V-labeling revealed that knockdown of miR-221 and miR-222 significantly increased cell apoptosis compared to the cells treated with scramble oligonucleotide (Fig. 4). In addition, caspase 3/7 activity was also considerably elevated in miR-221 and miR-222 knocked down cells (Fig. 5). Since collapse of the mitochondrial membrane potential is one of the early events in apoptosis (23), we next examined whether miR-221 and miR-222 regulate mitochondrial membrane potential. The cells with depletion of miR-221 and miR-222 were stained with cationic dye JC-1. FACSCalibur analysis showed that the mitochondrial membrane potential was largely damaged when miR-221 and miR222 were depleted (Fig. 6). These findings indicate that miR-221 and miR-222 play an important role in initiation of cell apoptosis(24). 

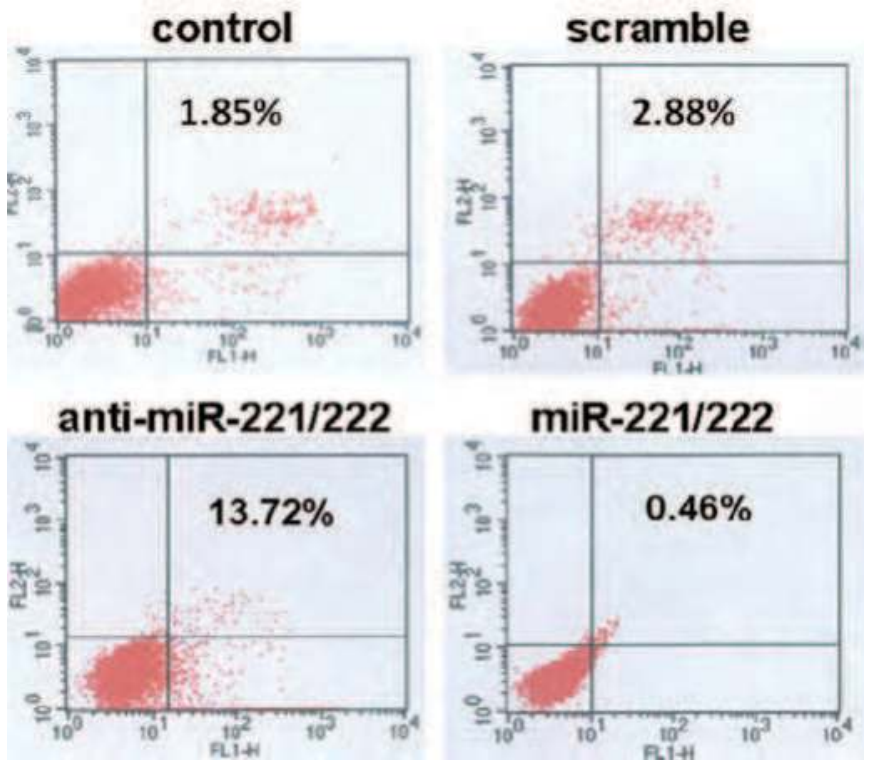

Fig. 4. Annexin V analysis showed that U251 cells transfected with As-miR-221/222 displayed significantly more apoptosis than the other three groups.

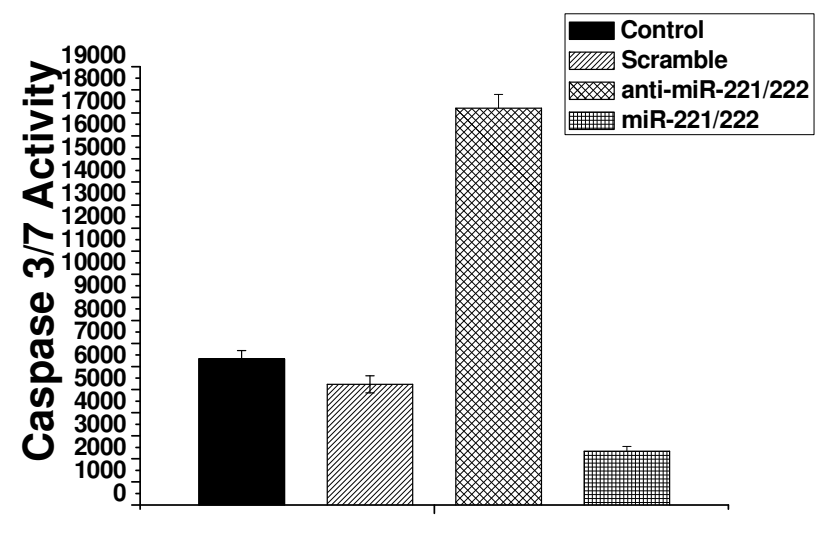

Fig. 5. Caspase 3/7 activity was considerably elevated in miR-221 and miR-222 knocked down cells compared to the other three group. 

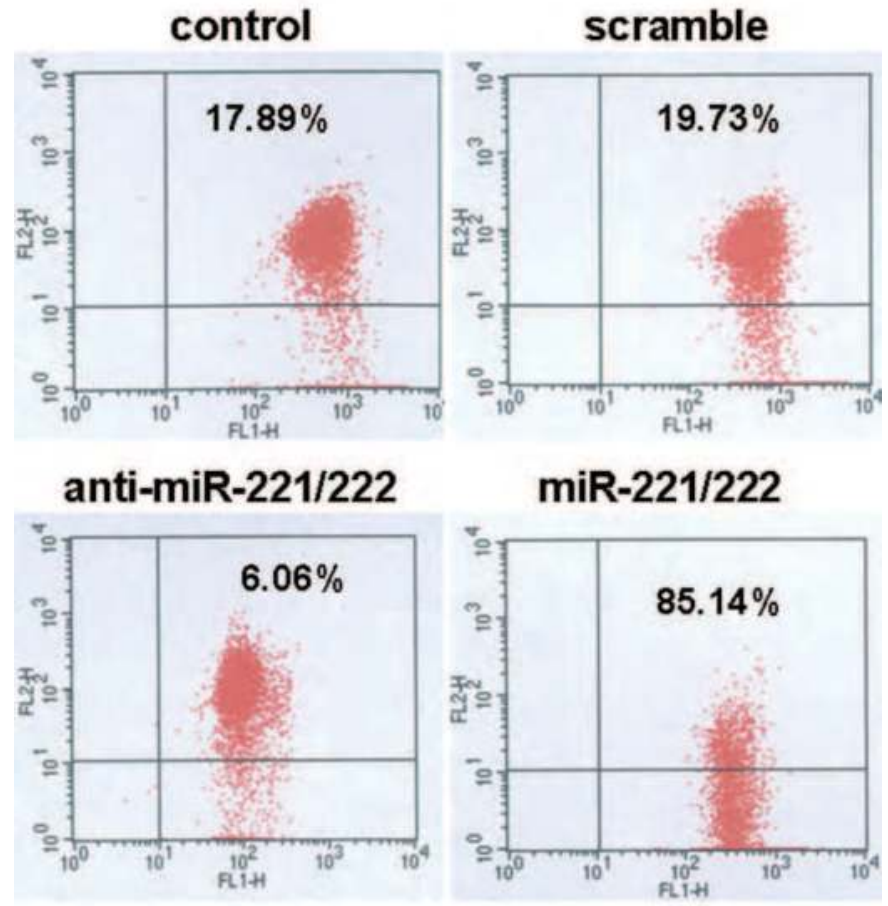

Fig. 6. U251 cells transfected with As-miR-221/222 showed a significantly greater collapse in mitochondrial membrane potential compared with the other four groups.

Furthermore, Garofalo $\mathrm{M}$ et al proved that miR-221/222 modulated TIMP3 expression by binding it's 3'UTR (25). Whether miR-221/222 modulated TIMP3 expression to affect glioma cell invasion or not. To further explore the role of miR-221/222 in cell invasion, we performed gain-of-function and loss-of-function analyses by over-expressing or suppressing miR-221/222 with anti-miR-221/222 or pMSCV-miR-221/222, respectively. Interestingly, the transwell assay revealed that knockdown of miR-221/222 significantly decreased cell invasion potential compared with cells treated with scrambled oligonucleotide, whereas over-expression of miR-221/222 increased cell invasion (Fig. 7). Consistent with the results of the transwell assay, in the wound healing assay, repression of miR-221/222 significantly inhibited cell migration, while over-expression of miR-221/222 increased migration in U251 cells (Fig. 8). Therefore, miR-221 and miR-222 are required for glioma cell invasion.

In addition to modulating proliferation, cell cycle, apoptosis and invasion, whether miR-221 and miR-222 regulated glioma cell radiosensitivity or not. To test this hypothesis, we transfected AS-miR-221/-222 into U251 cells, then preformed the colony formation assay to elevated radiosensitivity. Figure 9 shows the survival curves for U251 cells transfected with control, anti-miR-221/-222, and scrambled oligonucleotides and then exposed to IR over a dose range of 0 to $6 \mathrm{~Gy}$. We found that whereas scrambled oligonucleotides did not affect radiosensitivity, anti-miR-221/-222 transfection significantly decreased IR-induced survival. Radiation survival curves were characterized based on parameters such as the dose required to reduce survival to $37 \%$ of its value (D0), the surviving fraction at 2 Gy (SF2), and the sensitization enhancement ratio at $10 \%$ (SER10). The SER10 value for the U251 cells 
transfected with AS-miR-221/-222 was 1.97 (Table 1) ( $\mathrm{p}<0.01$ compared to the controls), indicating a radiosensitization potential for targeting miR-221/-222. Collectively, these observations provide strong evidence for the role of miR-221/-222 in regulation of radiosensitivity.

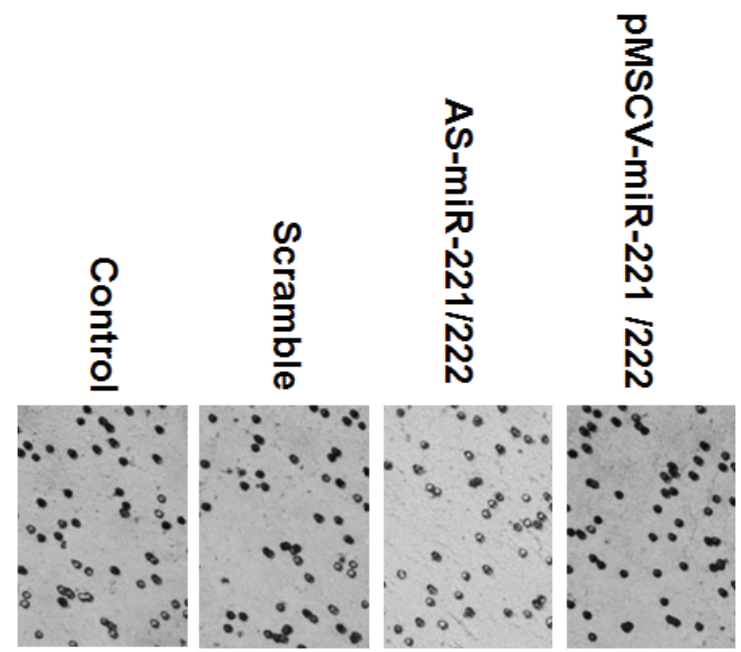

Fig. 7. The transwell assay revealed that knockdown of miR-221/222 significantly decreased cell invasion potential compared with cells treated with scrambled oligonucleotide, whereas over-expression of miR-221/222 increased cell invasion
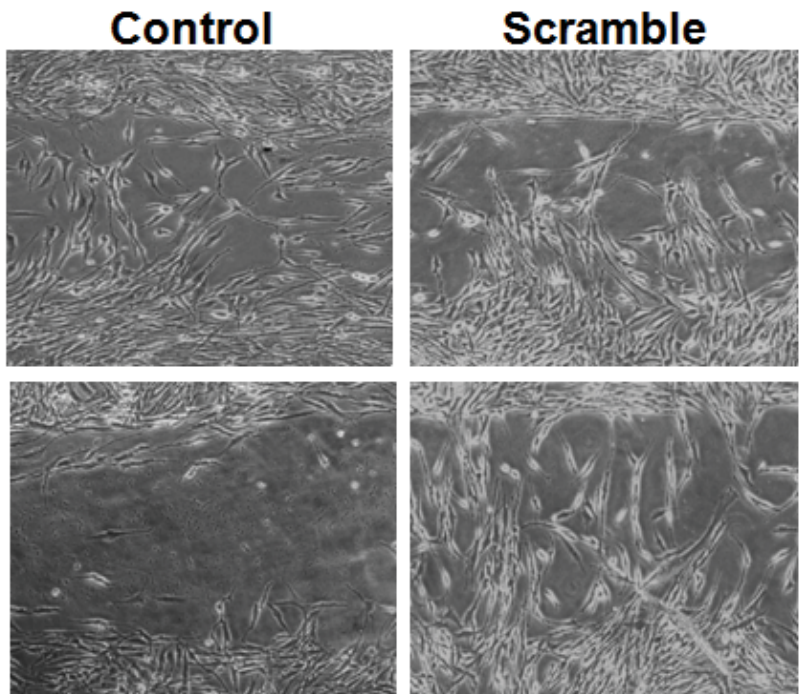

\section{AS-miR-221/222 pMSCV-miR-221/222}

Fig. 8. The wound healing assay, repression of miR-221/222 significantly inhibited cell migration, while over-expression of miR-221/222 increased migration in U251 cells 


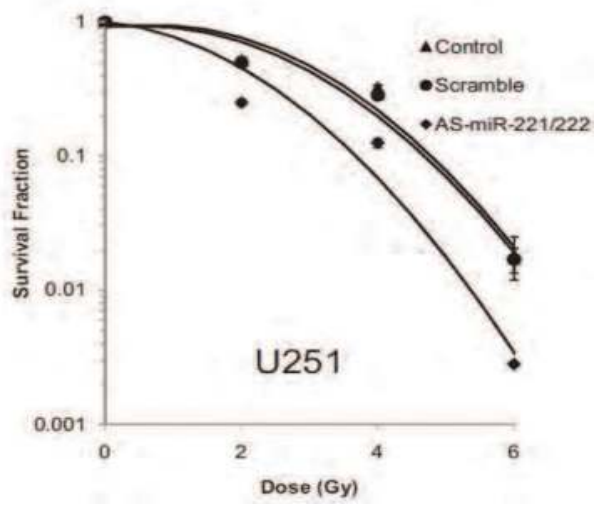

Fig. 9. miR-221/-222 knockdown leads to an increase of radiosensitivity. U251 cells stably transfected with control, AS-miR-221/-222, or scrambled ODN were exposed to 0 to 6 Gy IR and incubated for 2 weeks prior to fixation, staining, and assessment of colony formation. The clonogenic survival assays were performed in triplicate. Standard errors of the mean are shown by error bars.

\begin{tabular}{lllll}
\hline Cell & \multicolumn{1}{c}{ Group } & \multicolumn{1}{c}{$\mathrm{D}_{\mathrm{O}}$} & \multicolumn{1}{c}{ SF2 } & \multicolumn{1}{c}{ SER10 } \\
\hline U251 & Control & 2.8827 & 0.51 & 1 \\
& Scramble & 2.649 & 0.49 & 1.0731 \\
& AS-miR-221/-222 & $1.3656^{*}$ & $0.25^{*}$ & $1.9705^{*}$ \\
\hline
\end{tabular}

Abbreviations: $\mathrm{D} 0=$ dose to reduce survival to $37 \%$ of its value; SF2 = surviving fraction at 2 Gy; SER10 = sensitizer enhancement ratio at $10 \%$ survival. ${ }^{*} \mathrm{p}<0.01$.

Table 1. Radiosensitizing effects of respective cell lines

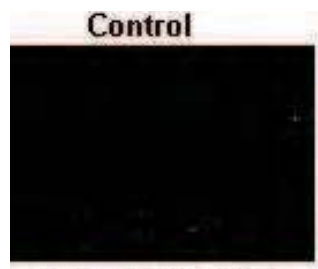

Anti-miR-221/222

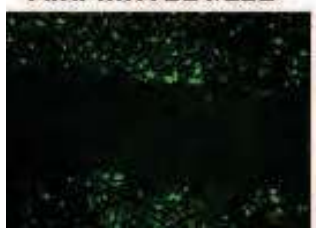

\section{Scramble}

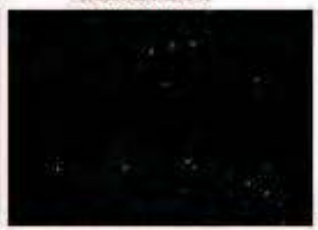

$\operatorname{miR}-221 / 222$

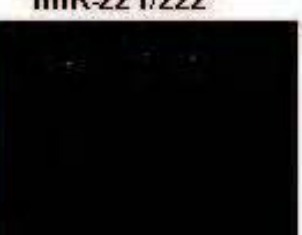

Fig. 10. SLDT assay showed that the functional GJIC in AS-miR-221/222 treated U251 cells were re-established, lucifer yellow was transferred to multiple rows of cells nearby the scrape border. 
In addition, by Scrape loading and dye transfer (SLDT) assay, we found that miR-221 and miR-222 also regulated gap junction intercellular communication (GJIC) of glioma cell.

\section{3 miR-221 and miR-222 cluster promote glioma growth in vivo}

In vitro, miR-221/222 modulated glioma cell growth by regulating cell cycle, apoptosis, and invasion, and so on. Whether these results are right or not in vivo. Ciafre et al firstly proved that the anti-miR-221/222 antagomir treatment of established subcutaneous tumors derived from the highly aggressive PC3 cell line, naturally expressing high levels of miR-221/222, reduces tumor growth by increasing intratumoral p27 amount; this effect is long lasting, as it is detectable as long as 25 days after the treatment(26). We used 5-week-old female immune-deficient nude mice (BALB/C-nu) to perform related experiment. It were housed in microisolator individually ventilated cages with water and food. All experimental procedures were carried out according to the regulations and internal biosafety and bioethics guidelines of Tianjin Medical University and the Tianjin Municipal Science and Technology Commission. U251 glioma subcutaneous model was established as previously described (27). When the volumer of the subcutaneous tumor reached $50 \mathrm{~mm}^{3}$, the mice were randomly divided into four groups (ten mice/group). A mixture of $5 \mu \mathrm{l}$ oligonucleotides containing Scr, AS-miR-221, AS-miR-222 or equal mount of AS-miR221/222 cluster and $10 \mu \mathrm{l}$ Lipofectamine was injected into the xenograft tumor model using a multi-site injection manner. Mice in U251 control group received $10 \mu \mathrm{l}$ of PBS only. Treatment was conducted one time every three days and five times in all (Please confirm if it is correct). The tumor volume was measured with a caliper every two days, using the formula volume $=$ length $\times$ width $2 / 2$.

Fluorescence in situ hybridization proved that As-miR-221 and As-miR-222 efficiently and specifically silenced endogenous miR-221 and miR-222, respectively, in xenograft tumor in vivo (Figure 11).Moveover, we have found that transfection of U251 cells with As-miR$221 / 222$ mediated significant inhibition of tumor growth in a xenograft tumor mouse model (Figure 12). Tumor pathological examination of xenograft tumors demonstrated that, in control and scramble group, more neonatal micro-vessels, bigger tumor cell nucleus, deeper blue staining chromosome, more mitotic tumor cells and lesser necrosis focuses were
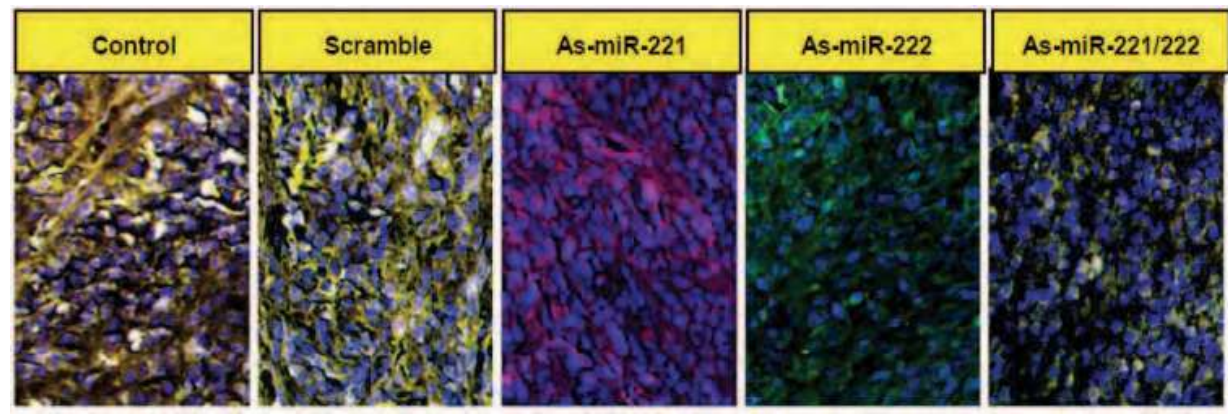

Fig. 11. Tumor pathological section of xenograft tumors show that miR-221 and miR-222 expression were knocked down by As-miR-221/222 in vivo by fluorescence in situ hybridization . 
observed than in As-miR-221/222 treatment group (Figure13). All these morphological changes among the three different treated groups indicate that the xenograft tumor without effective As-miR-221/222 therapy can perform relative more malignant pathological manifestation. TUNEL assay analysis of xenograft tumor taken at 28 days after treatment revealed much more apoptosis in As-miR221/222 group when compared to tumors from scramble and control groups (Figure14). Also, the As-miR-221/222 treated tumors had a lower level of Ki-67 expression compared to the other four groups group. Tumor immunochemistry examination of xenograft tumors demonstrated that some protein expression level in As-miR-221/222 group was up-regulated significantly than the other four groups, such as p27, puma, PTEN, TIMP3, and so on. Some protein expression levels in As-miR-221/222 group was down-regulated significantly than the other four groups, such as CyclinD, MMP2, MMP9, pAkt, and so on (Figure 15).

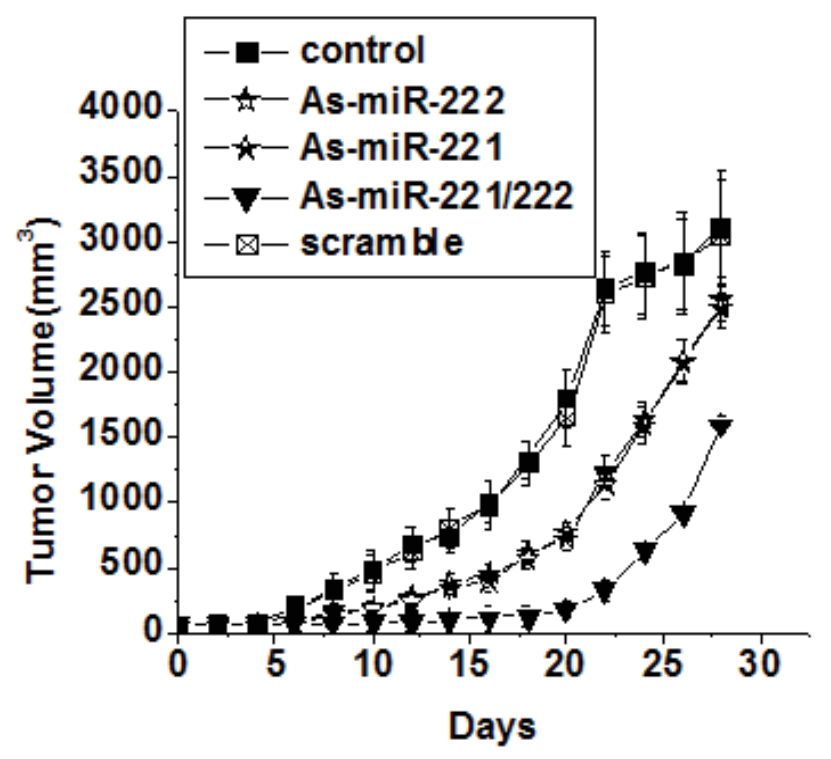

Fig. 12. Transfection of U251 cells with As-miR-221/222 mediated significant inhibition of tumor growth in a xenograft tumor mouse model. 


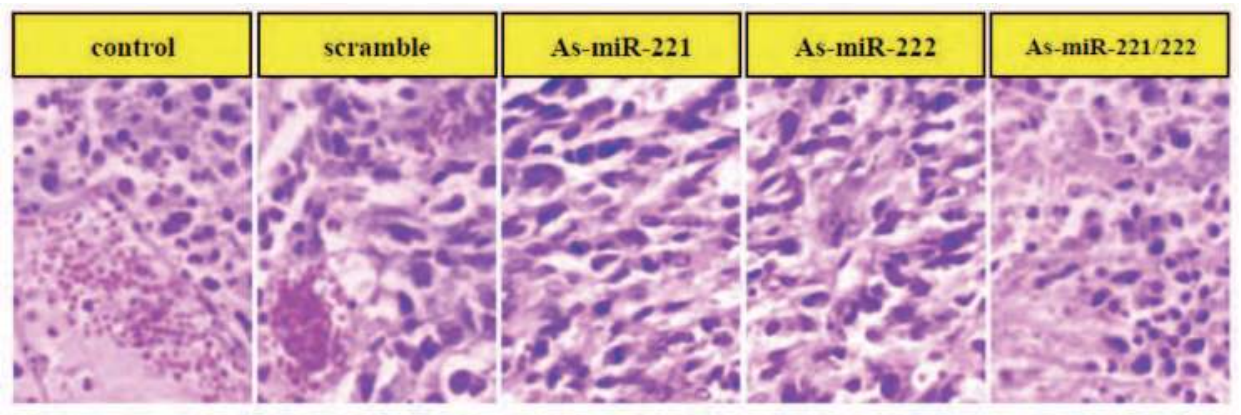

Fig. 13. Tumor pathological examination of xenograft tumors demonstrated that, in control and scramble group, more neonatal micro-vessels, bigger tumor cell nucleus, deeper blue staining chromosome, more mitotic tumor cells and lesser necrosis focuses were observed than in As-miR-221/222 treatment group.

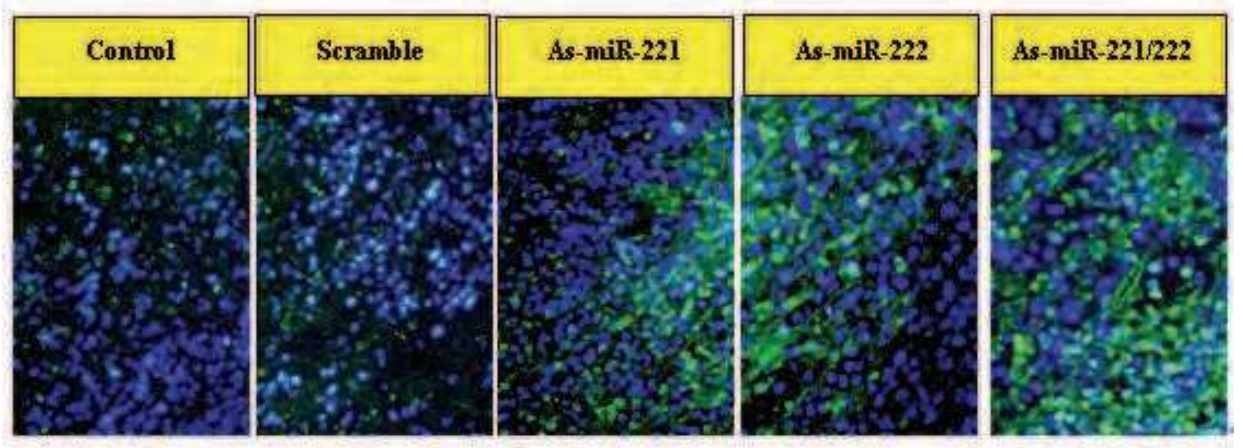

Fig. 14. TUNEL assay revealed much more apoptosis in As-miR221/222 group when compared to tumors from scramble and control groups. 


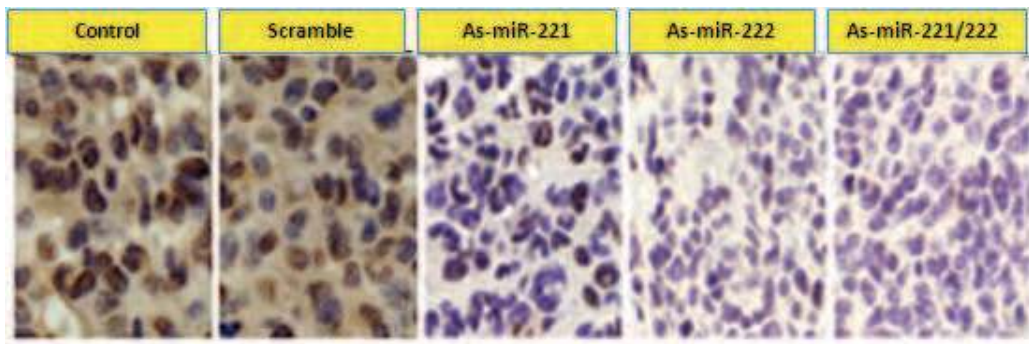

$\mathrm{Ki}-67$

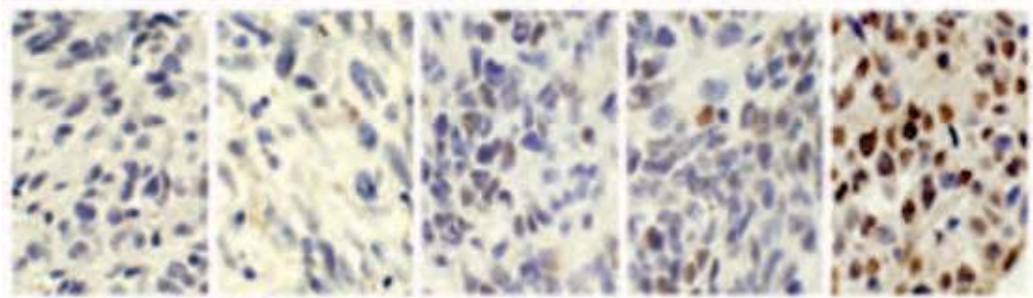

$p 27^{\text {kip1 }}$
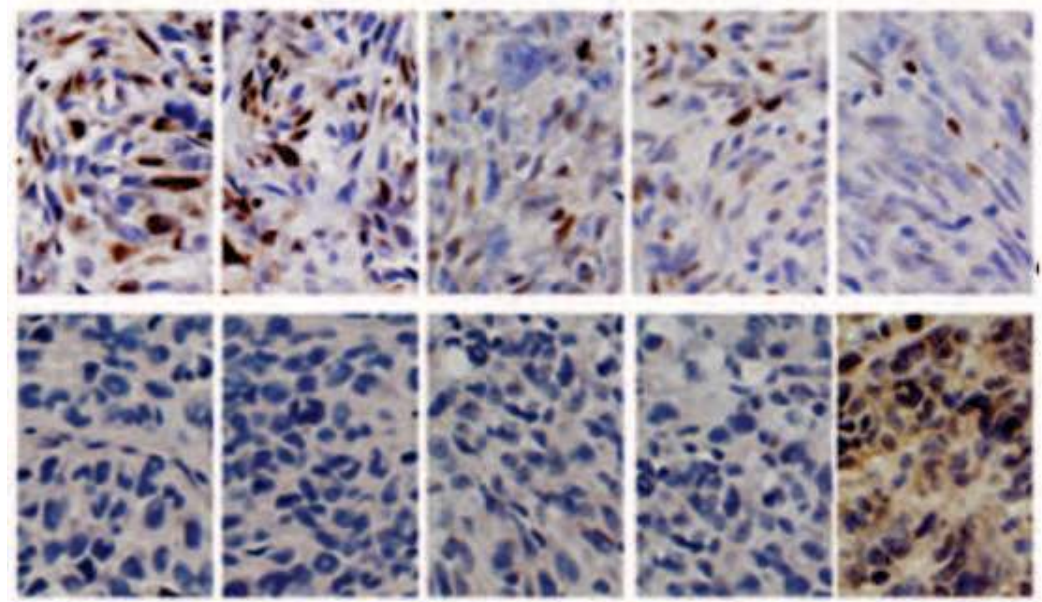

CyclinE
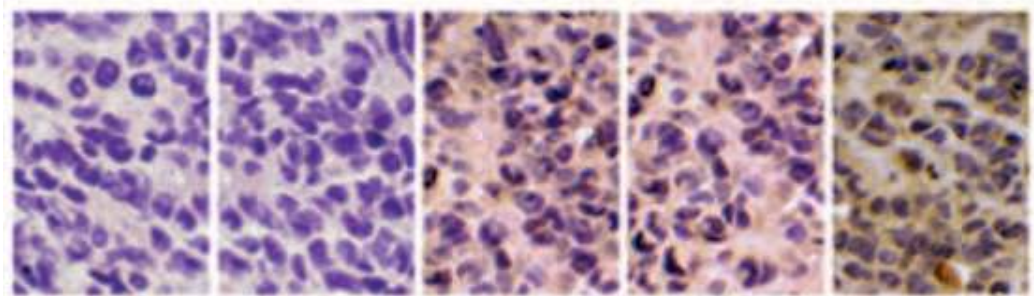

PUMA

Bax 

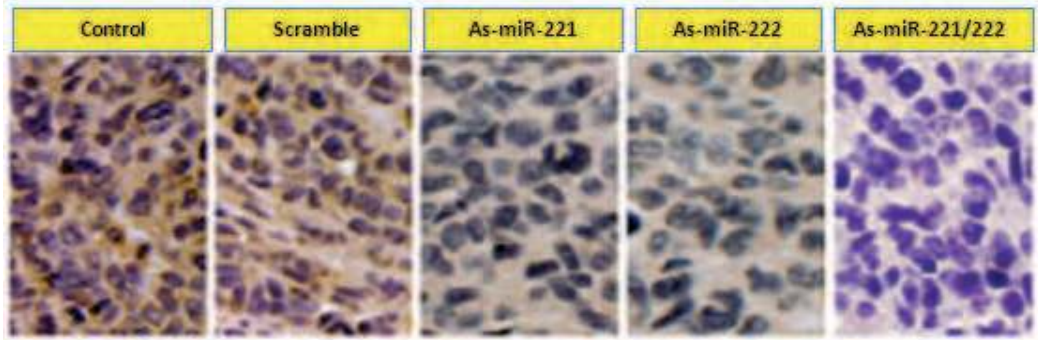

$\mathrm{Bcl}-2$
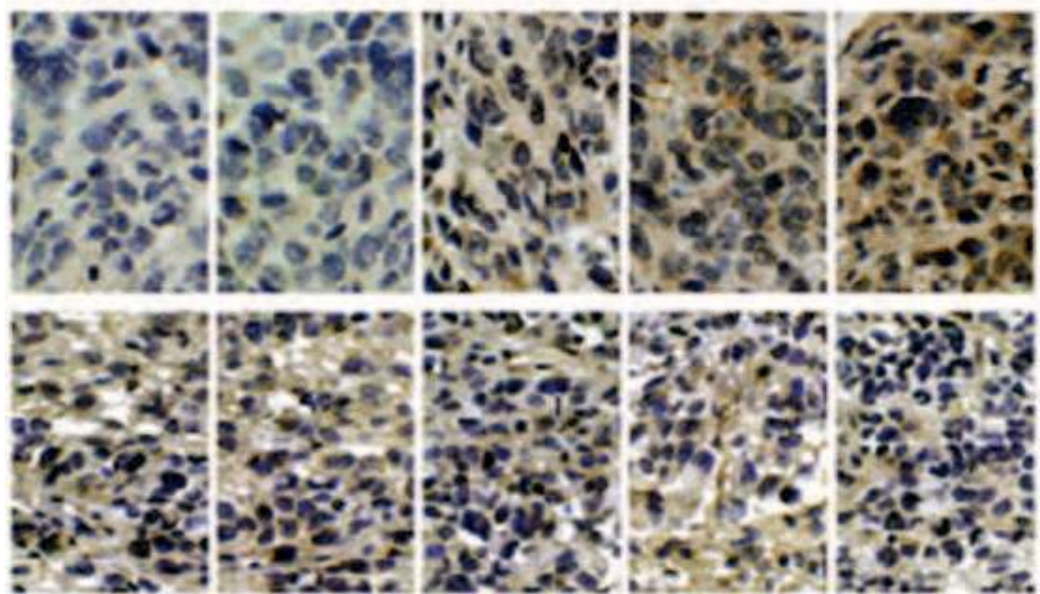

caspase 3
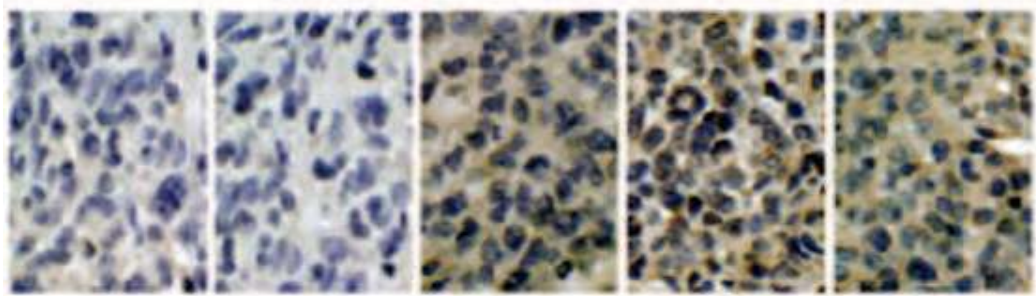

\section{p53}
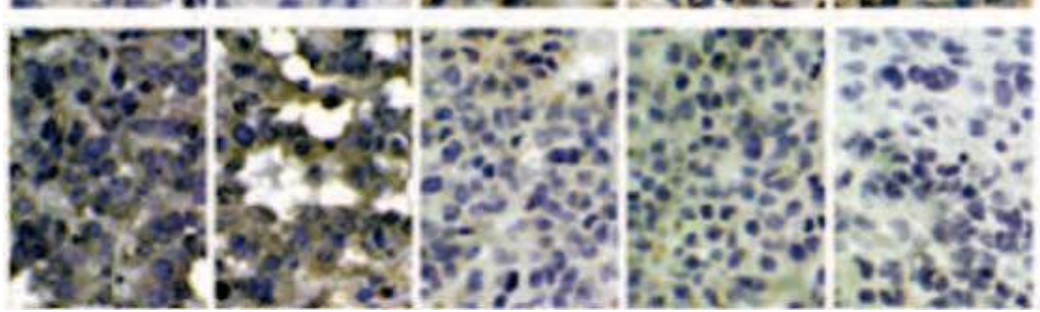

TIMP3

MMP2 


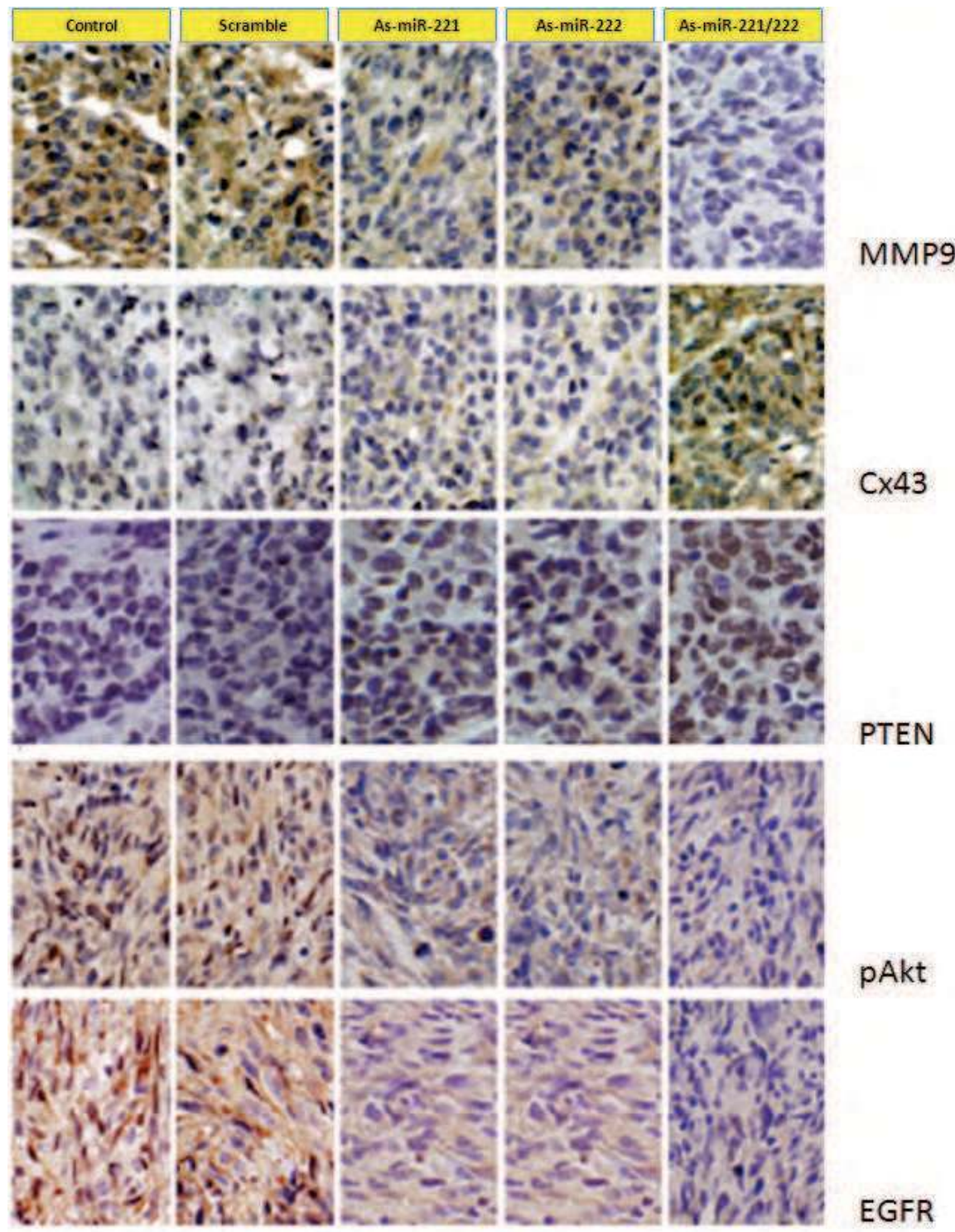

Fig. 15. Tumor immunochemistry examination of xenograft tumors demonstrated that some protein expression level in As-miR-221/222 group was up-regulated significantly than the other four groups and the other proteins expression level in As-miR-221/222 group was down-regulated. 


\subsection{The mechanism on miR-221 and miR-222 cluster modulate glioma cell malignant phenotype}

MiRs repress protein expression at the posttranscriptional level through imperfect base pairing with 3 untranslated region of the target mRNA in mammalian cells, leading to its reduced translation in order to affect cell function. That is, function of miRs depend on function of it target. So, it is necessary to identify targets of miRs. Bioinformatic analysis is the most effective approach to study miRNAs. We search some target by miRs target database, such as PicTar, TargetScan, and so on. Then, by luciferase assay, these targets were identified. As for miR-221 and miR-222, we proved that p27, PUMA, PTEN, TIMP3 and Cx43 were some targets of miR-221 and miR-222 in glioma.

\subsection{1 p2 ${ }^{\text {Kip1 }}$}

The p27Kip1 gene is a member of the cip/kip family of cyclin-dependent kinase (CDK) inhibitors that negatively control the cell cycle progression. The p27Kip1 binds to CDK2 and cyclin E complexes to prevent cell cycle progression from G1 to S phase $(28,29)$. The p27Kip1 does not follow Knudson's classic 'two-hit hypothesis' of tumor suppression. The inactivation of $\mathrm{p} 27 \mathrm{Kip} 1$ is not caused by direct mutations in the gene encoding $\mathrm{p} 27 \mathrm{Kip} 1$. The homozygous loss or silencing of the locus in human tumors is extremely rare (30). A recent study demonstrated that the miR-221/222 cluster is an endogenous regulator of p27Kip1, confirming the miRNA modulation may play a key role in the inactivation of p27Kip1 (31-34). However, that the miR-221/222 cluster affects tumor cell proliferation by regulating p27Kip1 in vivo has not been well documented.

\subsubsection{PUMA}

Puma was originally identified during large-scale analysis for novel p53-inducible genes and Bcl-2-interacting proteins. Puma is an extremely potent $\mathrm{BH}$-only protein, having the capacity to bind with high affinity to all known anti-apoptotic Bcl-2 proteins. In addition, Puma may also directly interact with and activate Bax/Bak, for example, through an interaction with the first $\alpha$-helix of Bax. In keeping with its highly pro-apoptotic nature, Puma has been shown to have an essential role in the induction of apoptosis in numerous in vitro and in vivo systems and cell types including neurons, lymphocytes, thymocytes, fibroblasts and cardiomyocytes. Puma expression is regulated by transcription, and factors regulating Puma ranscription include p53, p73, E2F and FOXO3a $(24,35)$.

\subsubsection{PTEN}

The PTEN (phosphatase and tensin homology) gene, located at 10q23.3, encodes a central domain with homology to the catalytic region of protein tyrosine phosphatases. It is important in the function of protein phosphatases and 3' -phosphoinositol phosphatase acivities. It dephosphorylates phosphatidylinositol-3,4,5-triphosphate(PIP3), the second messenger produced by PI3K. In do so, PTEN negatively regulates the activity of the serine/threonine protein kinase, $\mathrm{AKt}(36-37)$. PTEN is inactivated in some malignant tumors, including glioblastoma 、 prostate cancer、melanoma、 endometrial carcinoma and lung carcinoma. To restore PTEN expression become an approach which enhances cancer radiosensitivity instead of suppressing Akt activity in PTEN-deficient tumor cells(38).

\subsubsection{TIMP3}

Malignant glioma cells express certain known proteinases such as matrix metalloproteinases (MMPs), which have been implicated as important factors in regulating cell invasiveness in 
gliomas(39). MMPs are a family of at least 20 zinc-dependent endopeptidases collectively capable of degrading essentially all extracellular matrix(ECM) components, including collagents, fibronectin, laminin and basement membrance proteoglycans (40). Among the MMPs, attention has focused on gelatinases(MMP-2 and MMP-9) in human gliomas. A high level of MMP-2 expression was observed in the higher-grade gliomas, which correlated well with the malignant potential of human gliomas (41). A major mechanism for controlling MMPs activity in the pericellular space is mediated by the action of tissue inhibitors of metalloproteinases (TIMPs), which bind to active MMPs in a 1:1 molar stoichiometry (42). There are four family member, including TIMP-1, TIMP-2, TIMP-3, TIMP-4 (43). TIMP-3 is unique within the TIMP family as it remains closely associated to the extracellular matrix after being secreted by the cell $(40,44)$. In human gliomas, TIMP expression is reported to be down-regulated with increasing malignancy, including TIMP-3 (44).

\subsubsection{Cx43}

$\mathrm{Cx}$ genes have been demonstrated as tumor suppressor genes. Up to date, twenty members of $\mathrm{Cx}$ genes have been identified in mammalian tissues and they are expressed in tissue specific manner. Cx43 is the predominant form of Cxs expressed in astrocytes and also the constituent of connexons which compose the gap junction intercellular communication(GJIC) in brain (45, 46). Our previous study and other studies showed that $C x 43$ expression was inversely correlated with the degree of malignancy of astrocytomas (47). In most malignant gliomas, Cx43 expression was reduced or deleted and GJIC was deficient (47).

In addition these target above, c-kit, p57, $\mathrm{ER} \alpha, \mathrm{Bmf}$ are also is some target of miR-221 and miR-222, but they are not proved in glioma until now (48-51).

\subsection{Inter-relationship between miR-221 and miR-222 expression and global mRNA expression}

Studies above have identified some targets of miR-221 and miR-222, such as p27, p57, and so on. Inter-relationship between miR-221 and miR-222 expression and global mRNA expression remains important as well. Here we knocked down miR-221 and miR-222 expression and found 158 differentially expressed genes with 2-fold changes in U251 glioma cells by microarray analysis. Using the KEGG pathway databases and BioCarta, we found that the IFN-a signaling pathway was the most significant pathway modulated by differentially expressed genes. STAT1 and STAT2 are core proteins in the IFN-a signaling pathway. By Western blotting and immunofluorescence, we found that STAT1 and STAT2 expression and phosphorylation were upregulated in U251 cells with knocked-down miR221/222. Furthermore, tyrosine phosphorylation of STAT1 and STAT2 was present in the nucleus after repression of miR-221/222 expression in U251 cells. These data indicate for the first time a mechanism involving STAT1/2 upregulation under the transcriptional control of INF-asignaling after knockdown of miR-221/222 cluster in U251 glioma cells.

\subsection{Transcription factor modulate miR-221 and miR-222 expression}

MiRNAs finely modulate virtually all physiological pathways in metazoans, and are deeply implicated in all main pathologies by regulating their taregets. But who regulate them expression. Ciafrè et al report that the ectopic modulation of NF-kB modifies miR-221/222 expression in prostate carcinoma and glioblastoma cell lines, where we had previously shown their oncogenic activity. We identify two separate distal regions upstream of miR221/222 promoter which are bound by the NF-kB subunit p65 and drive efficient 
transcription in luciferase reporter assays; consistently, the site-directed mutagenesis disrupting p65 binding sites or the ectopical inhibition of NF-kB activity significantly reduce luciferase activity. In the most distal enhancer region, we also define a binding site for c-Jun, and we show that the binding of this factor cooperates with that of p65, fully accounting for the observed upregulation of miR-221/222. Thus, our work uncovers an additional mechanism through which NF-kB and c-Jun, two transcription factors deeply involved in cancer onset and progression, contribute to oncogenesis, by inducing miR-221/222 transcription (52).Moreover, Garofalo et al also identified that c-jun regulated miR-221 and miR-222 expression level.

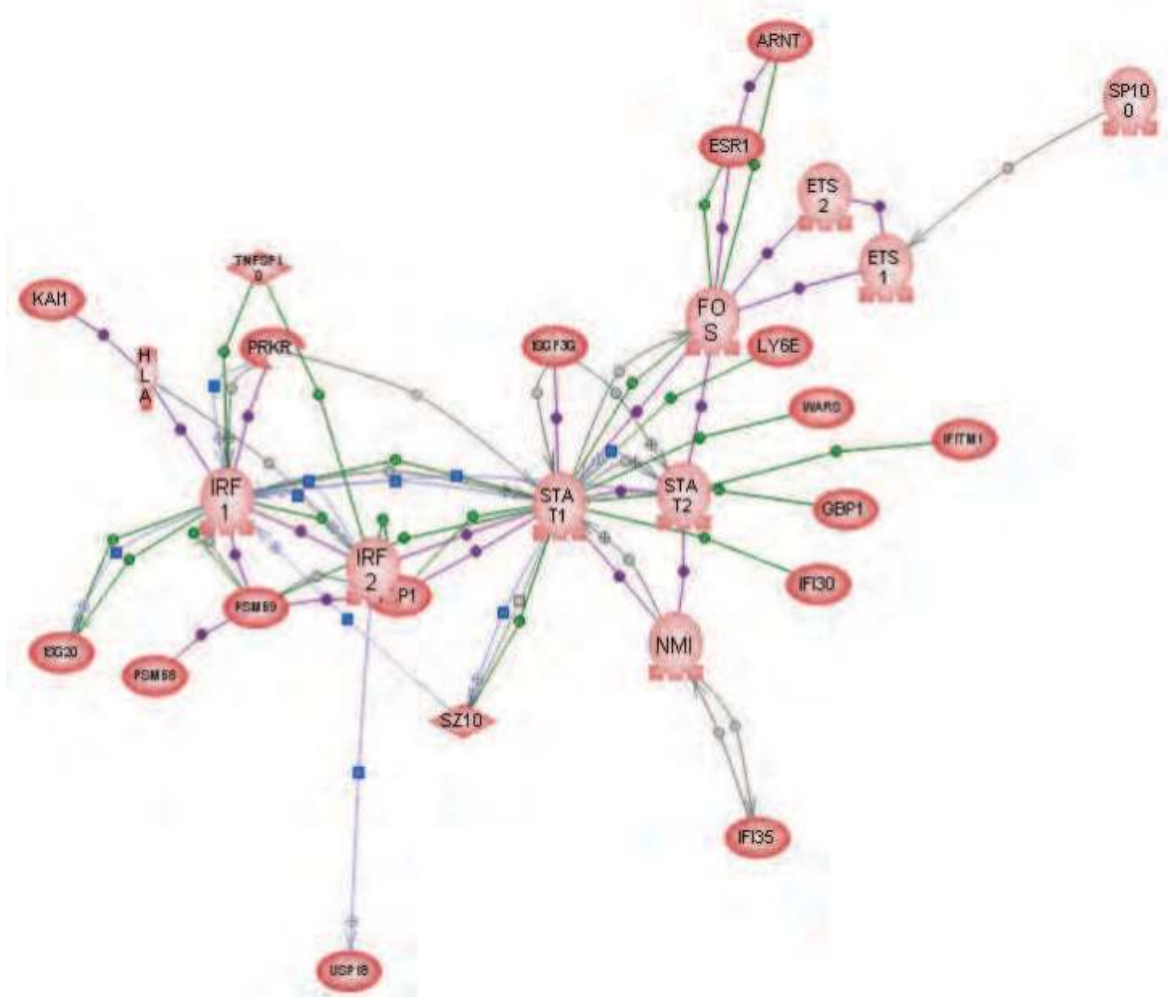

Fig. 16. Constructed network of miR-221/222-TFs-STAT1/2-gene expression. Genes involved in TF-gene expression in glioma U251 cells after repression of the miR-221/222 cluster, determining the cell death or survival through the INF- $\alpha$ pathway. Genes associated with eight TFs (FOS, ESR1,ETS2, IRF2, ARNT, ETS1, HOXC1, FOXN2) were manually identified via literature mining. IRF-1, STAT1 and STAT2 regulate the balance between miR-221/222-TFs and TF-gene expression, determining the cell death or survival through the INF- $\alpha$ pathway in glioma U251 cells. The INF- $\alpha$ pathway regulates cell survival negatively, via processes occurring in multiple intracellular compartments. Regulatory relationships are denoted by line colors, including the 28 genes and 64 verified modulation nodes. 


\section{Conclusion}

In summary, We first identified that miR-221 and miR-222 play an role in malignant phenotype of glioma by increasing or knocking down miR-221 and miR-222. It was found that miR-221/222 increased cell proliferation, increased $S$ phase proportionality, inhibited cell apoptosis, increased cell invasion and migration, enhanced radioresistance and reduced gap junction intercellular communication (GJIC) in glioma U251 cell. Furthermore, knockeddown miR-221/222 considerably decreases tumor growth in U251 cell xenograft model. Then, we identified that p27kip1, PUMA, PTEN, TIMP3 and Cx43 are some targets of miR-221 and miR-222. We also found that knocked down miR-221/222 changed some proteins expression. Taken together, our studies provide evidence that miR-221/222 regulate its target genes and its related transduction signal way to promote the growth of malignant glioma cells. So, we thought that miR-221 and miR-222 may serve as a novel therapeutic target for malignant gliomas.

\section{Acknowledgment}

Supported by China National Natural Scientific Found (30772231, 30901772), Tianjin Science and Technology Committee (07ZCGHHZ01000), and Program for New Century Excellent Talents in University (NCET-07-0615). The authors wish to thank Dr. R. Agami, Division of Tumor Biology, The Netherlands Cancer Institute, Amsterdam, Netherlands, for kindly providing the constructs of pGL3-p27-3'UTR and pGL3-p27-3'UTR-DM; and Dr. J.Q. Cheng, Molecular Oncology, H. Lee Moffitt Cancer Center, Tampa, USA, for kindly providing the protocol of miRNA Northern blotting. PH.D. Xu B, Department of Radiation Oncology, The Methodist Hospital Research Institute, Houston, TX, USA, for help in studying glioma cell radiosensitivity.

\section{References}

[1] Osada H, Takahashi T. MicroRNAs in biological processes and carcinogenesis. Carcinogenesis 2007,28:2-12.

[2] Zhang BH, Pan XP, Cobb GP, Anderson TA. MicroRNA as oncogenes and tumor suppressors. Developmental Biology. 2007,302:1-12.

[3] Dalmay T, Edwards DR. MicroRNAs and the hallmarks of cancer. Oncogene. 2006,25:6170-6175.

[4] Chen CZ. MicroRNAs as Oncogenes and Tumor Suppressors. New England Med, 2005, 353:1768-1771.

[5] George A .Calin, Carlo M.Croce, MicroRNA signatures in human cancers, Nature Reviews Cancer 6(2006)857-866.

[6] Metzler M, Wilda M, Busch K, Viehmann S, Borkhardt A, High expression of precursor microRNA-155/BIC RNA in children with Burkitt lymphoma, Genes Chromosomes Cancer 39(2004)167-169

[7] Michael MZ, O' Connor SM, van Holst Pellekaan NG, Young GP, James RJ, Reduced accumulation of specific microRNAs in colorectal neoplasia, Mol Cancer Res 1(2003) 882- 891. 
[8] Takamizawa J, Konishi H, Yanagisawa K, Tomida S, Osada H, Endoh H, Harano T,Yatabe Y, Nagino M, Nimura Y, Mitsudomi T, Takahashi T, Reduced expression of the let-7 microRNAs in human lung cancers in association with shortened postoperative survival, Cancer Res 64(2004) 3753-3756.

[9] Iorio MV, Ferracin M, Liu CG, Veronese A, Spizzo R, Sabbioni S, Magri E,Pedriali M, Fabbri M, Campiglio M, Ménard S, Palazzo JP, Rosenberg A, Musiani P, Volinia S, Nenci I, Calin GA, Querzoli P, Negrini M, Croce CM, MicroRNA gene expression deregulation in human breast cancer, Cancer Res 65(2005)7065-7070.

[10] He H, Jazdzewski K, Li W, Liyanarachchi S, Nagy R, Volinia S, Calin GA, Liu CG, Franssila K, Suster S, Kloos RT, Croce CM, de la Chapelle A, The role of microRNA genes in papillary thyroid carcinoma, Proc Natl Acad Sci U S A 102(2005)19075-19080

[11] Murakami Y, Yasuda T, Saigo K, Urashima T, Toyoda H, Okanoue T, Shimotohno K, Comprehensive analysis of microRNA expression patterns in hepatocellular carcinoma and non-tumorous tissues, Oncogene 25(2006)2537-2545.

[12] Chan JA, Krichevsky AM, Kosik KS, MicroRNA-21 is an antiapoptotic factor in human glioblastoma cells, Cancer Res 65(2005)6029-6033.

[13] Ciafrè SA, Galardi S, Mangiola A, Ferracin M, Liu CG, Sabatino G, Negrini M,Maira G, Croce CM, Farace MG, Extensive modulation of a set of microRNAs in primary glioblastoma, Biochem Biophys Res Commun 334(2005)1351-1358.

[14] Zhang lilei, Wang tao, Wright AF, et al. A microdeletion in Xp11.3 accounts for cosegregation of retinitis pigmentosa and mental retardation in a large kindred. American Journal of Medical Genetics.2006,140A:349-357.

[15] Branislav Kusenda, Marek Mraz, Jiri Mayer, et al. MicroRNA biogenesis, functionality and cancer relevance. Biomed Pap Med Fac Univ Palacky Olomouc Czech Repub. 2006, 150:205-215.

[16] Mishima T, Mizuguchi Y, Kawahigashi Y, et al. RT-PCR-based analysis of microRNA (miR-1 and -124) expression in mouse CNS. Brain Res, 2007,1131:37-43.

[17] Berezikov E, Thuemmler F, Van Laake LW, et al. Diversity of microRNAs in human and chimpanzee brain. Nat Genet,2006, 38:1375-1377.

[18] le Sage C, Nagel R, Egan DA, Schrier M, Mesman E, Mangiola A, Anile C, Maira G, Mercatelli N, Ciafrè SA, Farace MG, Agami R, Regulation of the p27(Kip1) tumor suppressor by miR-221 and miR-222 promotes cancer cell proliferation, EMBO J 26(2007)3699-3708.

[19] Frenquelli M, Muzio M, Scielzo C, Fazi C, Scarfo` L, Rossi L, Ferrari G, Ghia P, Caligaris-Cappio F. MicroRNA and proliferation control in chronic lymphocytic leukemia: functional relationship between miR-221/222 cluster and p27. Blood.2010, 115: 3949-3959.

[20] Galardi S, Mercatelli N, Giorda E, Massalini S, Frajese GV, Ciafrè SA, Farace MG, miR221 and miR-222 expression affects the proliferation potential of human prostate carcinoma cell lines by targeting p27Kip1, J Biol Chem 282( 2007)23716-23724.

[21] Visone R, Russo L, Pallante P, Martino ID, Ferraro A, Leone V, Borbone E, Petrocca F,Alder H, Croce2 CM, Fusco A. MicroRNAs (miR)-221 and miR-222, both overexpressed in human thyroid papillarycarcinomas, regulate p27Kip1 protein levels and cell cycle. Endocrine-Related Cancer.2007,14:791-798. 
[22] Sun K, Wang W, Zeng J, Wu C, Lei S, Li G. MicroRNA-221 inhibits CDKN1C/p57 expression in human colorectal carcinoma. Acta Pharmacologica Sinica (2011) 32: 375-384.

[23] Yee KS, Wilkinson S, James J, Ryan KM, Vousden KH: PUMA- and Baxinduced autophagy contributes to apoptosis. Cell Death Differ. 2009,16:1135-1145.

[24] Zhang C, Zhang J, Zhang A, Han L, Jia Z, Yang W, Wang G, You Y, Pu P, Cheng J, Kang C. MiR-221 and miR-222 target PUMA to induce Cell suvivall in glioblastoma. Molecular Cancer. 2010,9:229.

[25] Garofalo M, Leva GD, Romano G, Nuovo G, Suh SS, Ngankeu A, Taccioli C, Pichiorri F, Alder H, Secchiero P, Gasparini P, Gonelli A, Costinean S, Acunzo M, Condorelli G, Croce CM. MiR-221\&222 regulate TRAIL-resistance and enhance tumorigenicity through PTEN and TIMP3 down-regulation. Cancer Cell. 2009 , 16: 498-509.

[26] Mercatelli N, Coppola V, Bonci D, Miele F, Costantini A, Guadagnoli M, Bonanno E, Muto G, Frajese GV, Maria RD, Spagnoli LG, Farace MG, Ciafre SA. The Inhibition of the Highly Expressed Mir-221 and Mir-222 Impairs the Growth of Prostate Carcinoma Xenografts in Mice. PLoS one. 2008,3: e4029.

[27] Kang CS, Zhang ZY, Jia ZF, Wang GX, Qiu MZ, Zhou HX, Yu SZ, Chang J, Jiang H, Pu PY. Suppression of EGFR expression by antisense or small interference RNA inhibits U251 glioma cell growth in vitro and in vivo, Cancer Gene Ther.2006, 13:530-538.

[28] Blain SW, Scher HI, Cordon-Cardo C and Koff A. p27 as a target for cancer therapeutics. Cancer Cell.2003,3: 111-115.

[29] Chu IM, Hengst L and Slingerland JM. The Cdk inhibitor p27 in human cancer: prognostic potential andrelevance to anticancer therapy. Nat Rev. 2008, 8: 253-267.

[30] Philipp-Staheli J, Payne SR and Kemp CJ. p27Kip1: regulation and function of a haploin-sufficient tumor suppressor and its misregulation in cancer. Exp Cell Res.2001,264: 148-168.

[31] Le Sage C, Nagel R, Egan DA, Schrier M, Mesman E, Mangiola A, Anile C, Maira G, Mercatelli N, Ciafre SA, Farace MG and Agami R. Regulation of the p27 (Kip1) tumor suppressor by miR-221 and miR-222 promotes cancer cell proliferation. EMBO J.2007,26: 3699-3708.

[32] Galardi S, Mercatelli N, Giorda E, Massalini S, Frajese GV, Ciafre SA and Farace MG. miR-221 and miR-222 expression affects the proliferation potential of human prostate carcinoma cell lines by targeting p27Kip1. J Biol Chem.2007,282: 23716-23724.

[33] Garofalo M, Quintavalle C, Di Leva G, Zanca C, Romano G, Taccioli C, Liu CG, Croce $\mathrm{CM}$ and Condorelli G. MicroRNA signatures of TRAIL resistance in human nonsmall cell lung cancer. Oncogene . 2008 , 27:3845-3855.

[34] Chunzhi Zhang, Chunsheng Kang, Yongping You, Peiyu Pu, Weidong Yang, Peng Zhao, Guangxiu Wang, Anling Zhang, Zhifan Jia, Lei Han, Hao Jiang. Cosuppression of miR-221/222 cluster suppresses human glioma cells growth by targeting p27kip1 in vitro and in vivo. International Journal of Oncology. 2009, 34:1653-1660.

[35] Fricker M, O'Prey J, Tolkovsky AM and Ryan KM. Phosphorylation of Puma modulates its apoptotic function by regulating protein stability. Cell Death and Disease.2010, 1: e59 
[36] Sun YL, LK.St.Clair D, Fang F, Warren GW, Rangnekar VM, Crooks PA, St.Clair WH. The radiosensitization effect of parthenolide in prostate cancer cells is mediated by nuclear factor- $\kappa \mathrm{B}$ inhibition and enhanced by the presence of PTEN. Mol Cancer Ther. 2007,6:2477-2486.

[37] Jiang ZB, Pore N, Cerniglia GJ, Mick R, Georgescu MM, Bernhard EJ, Hahn SM, Gupta AK, Maity A. Phosphatase and tensin homologye deficiency in glioblastoma confers resistance to radiation and temozolomide that is reversed by the protease inhibitor nelfinavir. Cancer Res.2007,67:4467-4473.

[38] Pappas G, Zumstrin LA, Munshi A, Hobbs M, Meyn RE. Adenoviral-mediated PTEN expression radiosensitizes non-small cell lung cancer cells by suppressing DNA repair capacity. Cancer Gene Therapy.2007,14:543-549.

[39] Hsun-Jin Jan, Chin-Cheng Lee, Yung-Luen Shih, Dueng-Yuan Hueng, Hsin-I Ma, JingHuei Lai, Hen-Wei Wei and Horng-Mo Lee. Osteopontin regulates human glioma cell invasiveness and tumor growth in mice. Neuro-Oncology.2010,12:58-70.

[40] Paula Lam, Kar Sian Lim, Suk Mei Wang, Kam M.Hui. A mictoarry study to charaterize the molecular mechanism to TIMP-3-mediated tumor rejection. Molecular Therapy. 2005,12:144-152.

[41] Levicar N, Nuttall RK, Lah TT. Proteases in brain tumor progression. Acta Neurochir(Wien). 2003,145:825-838.

[42] Jiang Y, Goldberg I.D, Shi Y.E. Complex role of tissue inhibitor of metalloproteinases in cancer. Oncogene.2002,21:2245-2252.

[43] Brew.K, Dinakarpandian.D, Nagase.H. Tissue inhibitors of metalloproteinase: evolution, structure and function. Biochim. Biophys. Acta.2000,1477:267-283.

[44] Martine LM, Gianni D, Tung CH, Idema S, Schagen HE, Carette JE, Quax HA, Beusechem WV, Vandertop WP, Dirven MF, Chiocca EA, Gerritsen WR. Tissue inhibitor of metalloproteinase-3 expression from an oncolytic adenovirus inhibits matrix metalloproteinase activity in vivo without affecting antitumoral efficacy in malignant glioma. Cancer Res.2005,65:9398-9405.

[45] Yamasaki, H, Naus, CC. Role of connexin genes in growth control. Carcinogenesis 1996, 17: 1199-1213.

[46] Medina R, Zaidi SK, Liu CG, Stein JL, van Wijnen AJ, Croce CM, Stein GS. MicroRNAs 221 and 222 bypass quiescence and compromise cell survival. Cancer Res. 2008, 68: 2773-2780.

[47] Pu PY, Xia ZB, Yu SZ, Huang Q. Altered expression of Cx43 in astrocytic tumors. Clin Neurol Neurosurg 2004, 107: 49-54.

[48] Mayoral RJ, Monticelli S. Stable overexpression of miRNAs in bone marrow-derived murine mast cells using lentiviral expression vectors. Methods Mol Biol. 2010;667:20514.

[49] Fornari F, Gramantieri L, Ferracin M, Veronese A, Sabbioni S, Calin GA, Grazi GL, Giovannini C, Croce CM, Bolondi L, Negrini M. MiR-221 controls CDKN1C/p57 and CDKN1B/p27 expression in human hepatocellular carcinoma. Oncogene. 2008 , 27:5651-5661. 
[50] Zhao JJ, Lin J, Yang H, Kong W, He L, Ma X, Coppola D, Cheng JQ. MicroRNA$221 / 222$ negatively regulates estrogen receptor alpha and is associated with tamoxifen resistance in breast cancer.J Biol Chem. $2008,283: 31079-1086$.

[51] Gramantieri L, Fornari F, Ferracin M, Veronese A, Sabbioni S, Calin GA, Grazi GL, Croce CM, Bolondi L, Negrini M.MicroRNA-221 targets Bmf in hepatocellular carcinoma and correlates with tumor multifocality. Clin Cancer Res. 2009 Aug 15;15(16):5073-81.

[52] Galardi S, Mercatelli N, Farace MG, Ciafrè SA. NF-kB and c-Jun induce the expression of the oncogenic miR-221 and miR-222 in prostate carcinoma and glioblastoma cells. Nucleic Acids Research, 2011, doi:10.1093/nar/gkr006 


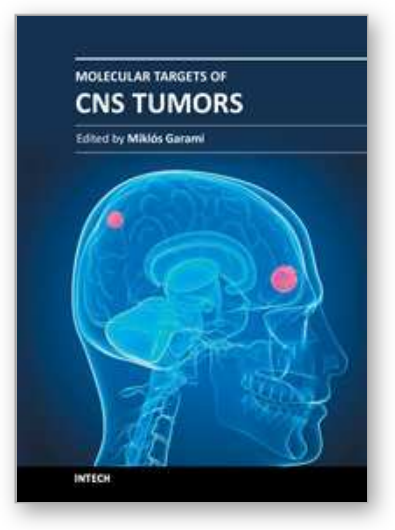

\author{
Molecular Targets of CNS Tumors \\ Edited by Dr. Miklos Garami
}

ISBN 978-953-307-736-9

Hard cover, 674 pages

Publisher InTech

Published online 22, September, 2011

Published in print edition September, 2011

Molecular Targets of CNS Tumors is a selected review of Central Nervous System (CNS) tumors with particular emphasis on signaling pathway of the most common CNS tumor types. To develop drugs which specifically attack the cancer cells requires an understanding of the distinct characteristics of those cells. Additional detailed information is provided on selected signal pathways in CNS tumors.

\title{
How to reference
}

In order to correctly reference this scholarly work, feel free to copy and paste the following:

Zhang Chunzhi, Jiang Tao, Wang Jinhuan, Cheng Jinquan, Pu Peiyu and Kang Chunsheng (2011). MiR221/222 Promote the Growth of Malignant Glioma Cells by Regulating Its Target Genes, Molecular Targets of CNS Tumors, Dr. Miklos Garami (Ed.), ISBN: 978-953-307-736-9, InTech, Available from: http://www.intechopen.com/books/molecular-targets-of-cns-tumors/mir-221-222-promote-the-growth-ofmalignant-glioma-cells-by-regulating-its-target-genes

\section{INTECH}

open science | open minds

\author{
InTech Europe \\ University Campus STeP Ri \\ Slavka Krautzeka 83/A \\ 51000 Rijeka, Croatia \\ Phone: +385 (51) 770447 \\ Fax: +385 (51) 686166 \\ www.intechopen.com
}

\author{
InTech China \\ Unit 405, Office Block, Hotel Equatorial Shanghai \\ No.65, Yan An Road (West), Shanghai, 200040, China \\ 中国上海市延安西路65号上海国际贵都大饭店办公楼 405 单元 \\ Phone: +86-21-62489820 \\ Fax: $+86-21-62489821$
}


(C) 2011 The Author(s). Licensee IntechOpen. This chapter is distributed under the terms of the Creative Commons Attribution-NonCommercialShareAlike-3.0 License, which permits use, distribution and reproduction for non-commercial purposes, provided the original is properly cited and derivative works building on this content are distributed under the same license. 